\title{
Renal transplantasyon hastalarında gözlenen deri bulgularının süreye göre değișiminin değerlendirilmesi
}

\author{
Evaluation of cutaneous manifestations according to \\ the time in renal transplant recipients
}

\section{Burhan Engin, Selma Alagöz*, Ali Reza Fenjanchi, Zekayi Kutlubay, Eneida Kote, Leyla Usmanova, Nurhan Seyahi*, Özden Öz Calay**, Ertuğrul Hasbi Aydemir}

İstanbul Üniversitesi, Cerrahpașa Tıp Fakültesi, Deri ve Zührevi Hastalıkları Anabilim Dalı,

*Nefroloji Bilim Dalı ve** Bioistatistik Anabilim Dalı, İstanbul, Türkiye

Özet

Amaç: Bu çalışmada renal transplant hastalarında görülen deri bulgularının sıklığı ve klinik özelliklerin belirlenmesi amaçlanmıştır.

Gereç ve Yöntem: Çalışmamızda renal transplantasyon yapılan 116 hastanın dosyaları retrospektif olarak incelendi. Altı aylık takip süreleri olan hastaların verileri değerlendirmeye alındı. Yaşları 10-68 arasında değişen (ortalama 36,62) 68 erkek $(\% 58,6)$ ve 48 kadın $(\% 41,4)$ hasta vardı. Hastaların detaylı dermatolojik muayeneleri yapıldı. Hastalar cinsiyet (erkek-kadın), transplantasyon süresi (1-5 yıl, 5-10 yıl ve 10 yıl üzeri), ve kullanılan ilaçlara (siklosporin, takrolimus, bu iki ilaç dışında immünosüpresan ilacı kullanan) göre gruplandıııldı.

Bulgular: Transplant hastalarında en sık görülen deri bulguları infeksiyon hastalıklarıydı. Deri bulguları onikomikoz (13), tinea pedis (9), akneiform lezyon (15) ve verruka (9) şeklinde kaydedildi. Altı ay sonraki klinik değerlendirmede benzer sonuçlar elde edildi. Klinik muayenede hastalarda \%7 premalin ve malin lezyon tespit edildi. Hasta gruplarına göre elde edilen sonuçlarda cinsiyet, transplantasyon süresi ve kullanılan ilaçların klinik bulguları etkilemediği belirlendi.

Sonuç: Renal transplant hastalarında dermatolojik muayene ve takipler uzun süreli olmalıdır. (Türkderm 2013; 47: 88-93)

Anahtar Kelimeler: Renal transplantasyon, immünsüprese ilaçlar

\section{Summary}

Background and Design: This study is conducted to determine the prevalence and clinical characteristics of cutaneous manifestations in renal transplant patients.

Materials and Methods: Hospital records of 116 renal transplant patients were retrospectively investigated. The data obtained from patients who had 6 months follow-up period were evaluated. There were 68 (58.6\%) males and 48 (41.4\%) females aged between 10 and 68 years (mean=36.6 years). Detailed dermatologic examination was performed. The patients were grouped according to gender (male-female), posttransplant period (1-5 years, 5-10 years, >10 years) and the drugs used (cyclosporin, tacrolimus, other than these two immunosuppressant drugs). Results: The most common cutaneous manifestations were infectious. The dermatological findings were onychomycosis (13), tinea pedis (9), acneiform disorders (15), and warts (9). The clinical evaluation after 6 months has also demonstrated the same result. Among the evaluated patients, 7\% showed premalignant or malignant manifestations on clinical examination. According to the results obtained from the patient groups, it was found that gender, length of post-transplant period, and use of immunosuppressant drugs do not influence the clinical manifestations of patients.

Conclusion: Dermatologic examinations and long-term follow-up should be performed in renal transplant patients. (Turkderm 2013; 47: 88-93) Key Words: Renal transplantation, immunosuppressant drugs

Yazışma Adresi/Address for Correspondence: Dr. Burhan Engin, İstanbul Üniversitesi Cerrahpaşa Tıp Fakültesi, Deri ve Zührevi Hastalıkları Anabilim Dalı, İstanbul, Türkiye Tel.: +90 21241431 19 E-posta: burhanengin2000@yahoo.com Geliş Tarihi/Received: 18.10.2012 Kabul Tarihi/Accepted: 13.11.2012

Türkderm-Deri Hastalıkları ve Frengi Arșivi Dergisi, Galenos Yayınevi tarafından basılmıștır. Turkderm-Archives of the Turkish Dermatology and Venerology, published by Galenos Publishing. 


\section{Giriş}

Renal transplantasyon, son dönem böbrek yetersizliğinin en iyi ve en ekonomik tedavisidir ${ }^{1}$. Transplantasyon bu hastalarda ilk tercih edilecek tedavi şeklidir. Son yıllarda transplant yönetimindeki ilerlemeler, özellikle immünsupresif tedavideki gelişmeler hasta yaşam süresini iyileştirmiştir². Ancak başarılı bir naklin devamı için gerekli olan immünsupresif ilaçlar, hem doğrudan etkileriyle, hem de immünsupresyona bağlı gelişen fırsatçı infeksiyonlara ikincil, deri bulgularına sebebiyet verebilirler.

Güncel rehberlere göre böbrek nakilli hastaların, özellikle deri kanserlerinin tanısında tecrübesi bulunan ve tercihen dermatolog olan doktorlar tarafından yıllık muayene edilmeleri önerilmektedir. Özellikle ülkemiz gibi çok güneş alan ülkelerde böbrek nakli sonrası deri ve dudak kanseri riskinin artmış olduğu bilinmektedir. Bu nedenlerle hastaların bulgularının gözlenmesi ve incelenmesi gereklidir. Biz bu çalışmamızda deri bulgularının sıklı̆̆ını, klinik özelliklerini ve ilaç gibi ilişkili faktörleri incelemeyi amaçladık 3 .

\section{Gereç ve Yöntem}

Hastanemiz Transplantasyon Ünitesinde kayıtlı toplam 450 hasta bulunmaktadır. Bu hastaların transplantasyondan sonraki birinci yılında bir aylık aralarla, birinci ve üçüncü yıllar arasında 2-3 aylık aralarla, dördüncü yıldan sonra ise 4-6 aylık aralarla kontrolleri yapılmakta olup deri bulguları bulunduğunda kaydedilmekte ve konsulte edilmektedir. 2010 Nisan ve 2012 Mayıs tarihleri arasında transplantasyon ünitesinde takip edilen ve dermatolog tarafından saptanmış dermatolojik şikayetleri olan toplam 116 transplantasyon hasta dosyası tarandı. Bu hastaların 6 ay sonraki dermatoloji kontrollerinin de olmasına dikkat edildi.

Hastalar muayene için geldiğinde tamamen soyunduruldu. Oral mukoza, genital bölge, saçlı deri ve tırnakların muayenesi her hasta için şikayet belirtmese de ayrıca yapıldı. Ayrıca tanıya yardımcı olabilecek diğer muayene yöntemlerine başvuruldu. Örneğin mantar infeksiyonu olan hastalardan direkt mantar bakısı, pitriyazis versikoloru olan hastalarda Wood ışı̆̆ı incelemesi ve nevüsü olan hastalarda dermoskopik muayene yapıldı ve gerekli tedavileri düzenlendi. Premalin ve malin lezyonu olanlarda ve diğer şüpheli durumlarda biyopsi alındı. Altı ay sonra hastaların tekrar muayeneleri yapılıp deri lezyonları kaydedildi. Hastalar cinsiyet, yaş, primer böbrek hastalığı, transplantasyon tarihi, nakil türü, eşlik eden diğer hastalıklar, kullandığı ilaçlar açısından detaylı olarak kaydedildi. Klinik muayenede tespit edilen deri lezyonları hasta cinsiyeti, transplantasyon süresi ve kullandığı ilaçlar göz önüne alınarak ayrı ayrı değerlendirildi.

Hastalar, transplantasyon süresi olarak 3 gruba (1-5 yıl, 5-10 yıl, 10 yıl ve üzeri ) ve ilaç kullanımı olarak 3 gruba (siklosoporin kullanan, takrolimus kullanan, bu 2 ilacın dışındaki immünsüpresifleri kullanan) ayrıldı. Bütün hastalarımız standart dozlarda ( $5 \mathrm{mg} / \mathrm{gün}$ prednizolon) prednizolon kullanmaktaydı. Siklosporin ve takrolimus kullanan hastalar aynı zamanda antiproliferatif ajan olarak mikofenolat mofetil veya mikofenolat sodyum kullanmaktaydı.

Elde ettiğimiz tüm veriler SPSS (istatistical packages for social analysis) programı kullanılarak ki-kare ve Fisher testleri ile değerlendirildi.

\section{Bulgular}

Araştırmaya katılan 116 hastanın 68'i erkek (\%58,6), 48'i $(\% 41,4)$ kadın idi. Yaş ortalaması 36,62 olarak tespit edildi. Transplantasyon tarihine göre 1. grupta (1-5 yıl) 43 hasta $(\% 37,1)$, 2. grupta (5-10 yıl) 42 hasta $(\% 36,2)$ ve 3 . grupta (>10 yll) 31 hasta $(\% 26,7)$ mevcuttu. Hastaların kullandığı ilaçlar sistemik kortikosteroid, siklosporin, takrolimus, azatiyoprin, mikofenolat sodyum, mikofenolat mofetil, sirolimus gibi ilaçların farklı kombinasyonlarından oluşuyordu. Illaç kullanımına göre gruplara ayrılan hastaların sayısı sırası ile 14 hasta siklosporin kullanan $(\% 12,1), 85$ hasta takrolimus kullanan $(\% 73,3)$, 17 hasta bu iki ilaç hariç diğer immünsüpresif ilaç kullananlar $(\% 14,7)$ şeklinde idi.

Dosyaları taranan 116 hastadan toplam 169 farklı deri bulgusu tespit edildi. Yetmiş sekiz hastada ise (\%67) birden fazla deri lezyonu saptandı. Altı ay sonraki takipte ise 145 farklı deri lezyonu tespit edilerek 49 (\%33) hastada birden fazla deri lezyonu saptandı. Hastalar klinik özelliklerine göre gruplandırılığında en sık infeksiyon hastalıklarının olduğu görüldü. Yirmi iki hastada tespit edilen mantar infeksiyonlarının tanıları tinea korporis (1), tinea pedis (9), onikomikoz (13) ve pitriyazis versikolor (4) şeklindeydi (5 hastada aynı anda hem tinea pedis hem de onikomikoz vardı). Bakteriyel infeksiyonlar folikülit (4), eritrazma (3), akneiform lezyon (15) ve apse (3) şeklinde toplam 23 hastada mevcuttu. Viral infeksiyon tespit edilen 15 hastada herpes simpleks (3), varisella infeksiyonu (3), ve verruka (9) mevcuttu. Bu verrukaların 2 tanesi genital siğil şeklindeydi. Hastaların 3 'ünde herpes simpleks ve genital siğil bir arada mevcuttu.

Altı ay sonraki takiplerde ise mantar enfeksiyonlarında (17) ve verrukalarda (4) azalma olurken akneiform lezyonlarda (18) artış kaydedildi. Illk kontrolde olmayan ve 6 ay sonraki takipte bir hastada yeni ortaya çıkan mantar infeksiyonu ve yine bir hastada ortaya çıkan genital siğil kaydedildi.

Ağız içi lezyonlar oral aft (1), erozyon (2), lökoplaki (1) şeklinde idi. Ağız içinde ayrıca non-spesifik olarak kuruluk, fissür ve coğrafik dil tespit edildi. Premalin ve malin lezyonlar toplam 9 hastada gözlendi. Dört hastada solar lentigo, 1 hastada displastik nevüs, 1 hastada bazal hücreli kanser (BHK), 3 hastada dev konjenital nevüs tespit edildi.

Cinsiyete Göre Deri Bulguları

Erkeklerde başlangıçta en sık görülen deri lezyonları (Tablo 1); mantar infeksiyonu (17), kserosis (13), viral infeksiyon (10), akneiform lezyon (9), hiperpigmentasyon (5), seboreik keratoz, seboreik dermatit ve pruritus şeklindeydi. Altı ay sonraki değerlendirmede en sık görülen deri lezyonu yine mantar infeksiyonu (15) idi. Akneiform lezyon (15), kserosis (8), folikülit (6), seboreik keratoz (4), melanositik nevüs, eritrazma, dermal nevüs 6 ay sonraki değerlendirmede sırasıyla mantar infeksiyonlarını takip ettiler. Ayrıca 22 hastada androgenetik alopesi ve 2 hastada da pull test pozitif tespit edildi.

Kadınlarda en sık görülen deri bulguları; kserosis (14), akneiform lezyon (6), hiperpigmentasyon (5), mantar infeksiyonu (5), viral infeksiyon (5), dermal nevüs, kuperoz, stria, telenjiyektazi, ağız içi lezyonlar şeklindeydi. Sonraki takipte ise yine en sık görülen deri bulgusu kserosis (11) idi. ikinci sırada ise seboreik dermatit (8) belirgin olarak artış gösterdi. Akneiform lezyonlar (3) ve viral enfeksiyonlarda (2) ise azalma gözlendi. 
En sık görülen deri bulgusu olan yüzeyel mantar infeksiyonları erkek cinsiyette daha fazla oranda tespit edildi ancak istatistiksel olarak cinsiyetler arasında anlamlı fark saptanmadı $(p=0,11)$. Viral ve bakteriyel deri infeksiyonları yine erkek hastalarda daha sık tespit edildi, aynı şekilde cinsiyetler arasında anlamlı farklılık yoktu $(p=0,29$ ve $p=0,52$ ).

Premalin ve malin lezyonlar toplam 9 hastada gözlendi. Cinsiyet açısından istatistiksel olarak anlamlı bir fark saptanmadı $(p=0,2)$.

\section{Transplantasyon süresine göre deri bulguları}

Transplantasyon süresi 1-5 yıl arasında olan hastalarda en sık görülen deri bulgusu kserosis (13) idi. Ancak bu oran diğer grup hastalarda (transplantasyon yılı artan gruplar) giderek azalma gösterdi. Mantar infeksiyonu 11 (\%25), akneiform lezyon (6), hiperpigmentasyon (5), hiperkeratoz (3) sırasıyla kserosisi takip etti. Bir sonraki takipte kserosis (5) olgularında belirgin bir azalma, akneiform lezyonlar (8) ve mantar infeksiyonlarında (12) hafif bir artış gözlendi.

Transplantasyon süresi 5-10 yıl arasında olan hastalarda ise en sık görülen deri lezyonu viral infeksiyonlar oldu (10). Kserosis (8), mantar infeksiyonu 8 (\%19), akneiform lezyon (6), hiperpigmentasyon (3) rastlanan diğer lezyonlar idi. Bu grupta viral infeksiyonlarda artış

\section{Tablo 1. Deri bulgularının cinsiyete göre dağılımı}

\begin{tabular}{|l|c|c|c|}
\hline Deri bulguları & $\mathbf{n}(\%)$ & Erkek & Kadın \\
\hline Kserosis & $27(23)$ & 13 & 14 \\
\hline Mantar enfeksiyonu & $22(18)$ & 17 & 5 \\
\hline Akneiform lezyon & $15(13)$ & 9 & 6 \\
\hline Viral enfeksiyon & $15(13)$ & 10 & 5 \\
\hline Hiperpigmentasyon & $10(8)$ & 5 & 5 \\
\hline Kuperoz & $6(5)$ & 3 & 3 \\
\hline Seboreik dermatit & $5(4)$ & 4 & 1 \\
\hline Dermal nevus & $5(4)$ & 1 & 4 \\
\hline Ağız içi lezyon & $5(4)$ & 3 & 2 \\
\hline Seboreik keratoz & $5(4)$ & 5 & 0 \\
\hline Pruritus & $4(3)$ & 4 & 0 \\
\hline Folikülit & $4(3)$ & 2 & 1 \\
\hline Telenjiyektazi & $4(3)$ & 2 & 2 \\
\hline Solar lentigo & $4(3)$ & 3 & 1 \\
\hline Hiperkeratoz & $3(2)$ & 2 & 1 \\
\hline Eritrazma & $3(2)$ & 2 & 1 \\
\hline Konjenital dev nevus & $3(2)$ & 2 & 1 \\
\hline Ekzema & $3(2)$ & 2 & 1 \\
\hline Stria & $3(2)$ & 0 & 3 \\
\hline Efelid & $2(1)$ & 0 & 2 \\
\hline Melanositik nevus & $2(1)$ & 2 & 0 \\
\hline Displastik nevus & $1(1)$ & 1 & 0 \\
\hline BHK & $1(1)$ & 1 & 1 \\
\hline Diffüz saç seyrelmesi & $1(1)$ & 1 & 0 \\
\hline Granulom anülare & $1(1)$ & 0 & 0 \\
\hline Ekskoriye plak, nodül & $1(1)$ & & 1 \\
\hline
\end{tabular}

göze çarpan bulgu oldu. Sonraki takipte en belirgin değişim viral infeksiyonlarda azalma (1) şeklindeydi. Mantar infeksiyonu (9), kserosis (8) ve akneiform (5) lezyonlarda belirgin bir değişiklik gözlenmedi. Transplantasyon süresi 10 yı üzerinde olan hastalarda kserosis (6) en sık rastlanan bulgu idi. Telenjiyektazi (4), viral enfeksiyon (4), mantar infeksiyonu (3) sırasıyla izlenen lezyonlardı. Bu grupta ise mantar ve viral enfeksiyonların sıkığındaki azalma göze çarptı. Sonraki takipte kserosis (6), viral infeksiyon (1), mantar infeksiyonları (3) tespit edildi. Yüzeyel mantar infeksiyonları ve bakteriyel infeksiyonlarda gruplar arasında istatistiksel olarak anlamlı fark saptanmadı $(p=0,22$ ve 0,60$)$, ancak viral infeksiyonlarda gruplar arasında istatistiksel olarak anlamlı farkllık tespit edildi $(p=0,013)$.

Malin ve premalin lezyonlarda gruplar arasında istatistiksel olarak anlamlı fark saptanmadı $(p=0,88)$.

\section{ìlaç kullanımına göre deri bulguları}

Siklosporin kullanan hastalarda kserosis (6) en çok görülen bulgu idi. Mantar infeksiyonları 3 (\%21), viral infeksiyonlar 2 (\%14),

\section{Tablo 2. İlaçlara göre deri bulgularının dağılımı}

\begin{tabular}{|c|c|c|c|c|}
\hline Deri bulguları & n (\%) & $\begin{array}{c}\text { Grup A } \\
\text { (n) }\end{array}$ & $\begin{array}{c}\text { Grup B } \\
\text { (n) }\end{array}$ & $\begin{array}{c}\text { Grup C } \\
\text { (n) }\end{array}$ \\
\hline Kserosis & $27(23)$ & 6 & 17 & 4 \\
\hline Mantar enfeksiyonu & $22(18)$ & 3 & 14 & 5 \\
\hline Akneiform lezyon & $15(13)$ & 2 & 11 & 2 \\
\hline Viral enfeksiyon & $15(13)$ & 2 & 9 & 4 \\
\hline Hiperpigmentasyon & $10(8)$ & 1 & 7 & 2 \\
\hline Kuperoz & $6(5)$ & 0 & 2 & 4 \\
\hline Seboreik dermatit & $5(4)$ & 1 & 2 & 2 \\
\hline Dermal nevus & $5(4)$ & 0 & 4 & 1 \\
\hline Ağız içi lezyon & $5(4)$ & 0 & 3 & 2 \\
\hline Seboreik keratoz & $5(4)$ & 1 & 1 & 3 \\
\hline Pruritus & $4(3)$ & 0 & 4 & 0 \\
\hline Folikülit & $4(3)$ & 0 & 4 & 0 \\
\hline Telenjiyektazi & $4(3)$ & 1 & 2 & 1 \\
\hline Solar lentigo & $4(3)$ & 0 & 2 & 2 \\
\hline Hiperkeratoz & $3(2)$ & 1 & 2 & 0 \\
\hline Eritrazma & $3(2)$ & 0 & 2 & 1 \\
\hline Konjenital dev nevus & $3(2)$ & 0 & 3 & 0 \\
\hline Ekzema & $3(2)$ & 0 & 2 & 1 \\
\hline Stria & $3(2)$ & 2 & 1 & 0 \\
\hline Efelid & $2(1)$ & 0 & 2 & 0 \\
\hline Melanositik nevus & $2(1)$ & 0 & 2 & 0 \\
\hline Displastik nevus & $1(1)$ & 0 & 1 & 0 \\
\hline BHK & $1(1)$ & 1 & 0 & 0 \\
\hline Diffüz saç seyrelmesi & $1(1)$ & 1 & 0 & 0 \\
\hline Granulom anülare & $1(1)$ & 0 & 1 & 0 \\
\hline Ekskoriye plak, nodül & $1(1)$ & 0 & 1 & 0 \\
\hline
\end{tabular}

Grup A: Siklosporin kullanan, Grup B: Takrolimus kullanan, Grup C: Siklosporin ve takrolimus kullanmayan (Bütün hastalar standart dozlarda prednizolon kullanmaktaydı) 
akneiform lezyonlar (2), stria (2), seboreik dermatit, hiperkeratoz, hiperpigmentasyon, seboreik keratoz diğer görülen lezyonlardı. Bu grupta dikkati çeken husus genel olarak lezyonların daha az görülmesi idi. Bu grupta sonraki kontrolde kserosis (2), mantar (2) ve viral infeksiyonlarda (0) belirgin bir azalma tespit edildi.

Takrolimus kullanan hastalarda kserosis (17), mantar infeksiyonu (14), akneiform lezyon (11), viral infeksiyon (9), hiperpigmentasyon (7), telenjiyektazi, pruritus, dermal nevüs ve folikülit tespit edilen hastalıklardı. Altı ay sonraki takipte ise mantar infeksiyonlarında (21) artış, kserosis (15) ve viral infeksiyonlarda (3) azalma ve akneiform lezyonlarda (11) fazla bir değişiklik saptanmadı.

Siklosporin ve takrolimus kullanmayan grupta ise mantar infeksiyonu (5), kserosis (4), viral infeksiyon (4) ve kuperoz (4), ağız içi lezyon (2), telenjiyektazi, akneiform lezyon, eritrazma, seboreik dermatit tespit edilen diğer lezyonlardı. Bu grupta ise mantar infeksiyonlarda (7) artış, viral infeksiyonlarda (1) ve kserosiste (0) azalma saptandı.
İlaç kullanımına göre istatistiksel olarak değerlendirildiğinde yüzeyel mantar, bakteriyel ve viral infeksiyon sıklığında gruplar arasında anlamlı farklılık saptanmadı ( $p=0,44,0,87$ ve 0,34$)$.

Malin ve premalin lezyonlar ise 1.grupta 2 (\%14), 2. grupta $5(\% 5)$, 3. grupta 1 (\%5) hastada gözlendi. Bu veriler gruplar arasında istatistiksel olarak anlamlı fark ifade etmedi $(p=0,50)$.

\section{Tartışma}

Bu çalışmada renal transplantasyon yapılan hastalarda tespit edilen deri bulgularının normal populasyona göre artmış olduğu gözlenmiştir 4,5 . Özellikle immünsupresif tedavi kullanımına bağlı olarak bir çalışmada olduğu gibi infeksiyöz hastalıklar ön planda görülmektedirø. Bunlar içinde yüzeyel mantar infeksiyonları, bakteriyel ve viral infeksiyonlar sayılabilir. Yüzeyel mantar infeksiyonları renal transplantasyon yapılan hastalarda en sık görülen deri bulgusu olarak belirlendi. Ghaninejad8 ve Sandoval9' ${ }^{\prime}$ in çalışmalarında da mantar infeksiyonları en çok görülen

Tablo 3. Transplantasyon yılı ile ilişkili deri bulguları

\begin{tabular}{|c|c|c|c|c|}
\hline Deri bulguları & n (\%) & Grup 1 (n) & Grup 2 (n) & Grup $3(n)$ \\
\hline Kserosis & $27(23)$ & 13 & 8 & 6 \\
\hline Mantar enfeksiyonu & $22(18)$ & 11 & 8 & 3 \\
\hline Akneiform lezyon & $15(13)$ & 6 & 6 & 3 \\
\hline Viral enfeksiyon & $15(13)$ & 1 & 10 & 4 \\
\hline Hiperpigmentasyon & $10(8)$ & 5 & 3 & 2 \\
\hline Kuperoz & $6(5)$ & 0 & 3 & 3 \\
\hline Seboreik dermatit & $5(4)$ & 1 & 3 & 1 \\
\hline Dermal nevus & $5(4)$ & 3 & 2 & 0 \\
\hline Ağız içi lezyon & $5(4)$ & 2 & 1 & 2 \\
\hline Seboreik keratoz & $5(4)$ & 1 & 1 & 3 \\
\hline Pruritus & $4(3)$ & 2 & 2 & 0 \\
\hline Folikülit & $4(3)$ & 1 & 2 & 1 \\
\hline Telenjiyektazi & $4(3)$ & 2 & 0 & 2 \\
\hline Solar lentigo & $4(3)$ & 2 & 1 & 1 \\
\hline Hiperkeratoz & $3(2)$ & 2 & 1 & 0 \\
\hline Eritrazma & $3(2)$ & 0 & 2 & 1 \\
\hline Konjenital dev nevus & $3(2)$ & 1 & 1 & 1 \\
\hline Ekzema & $3(2)$ & 2 & 1 & 0 \\
\hline Stria & $3(2)$ & 0 & 0 & 3 \\
\hline Efelid & $2(1)$ & 0 & 1 & 1 \\
\hline Melanositik nevus & $2(1)$ & 1 & 1 & 0 \\
\hline Displastik nevus & $1(1)$ & 0 & 0 & 1 \\
\hline $\mathrm{BHK}$ & $1(1)$ & 0 & 1 & 0 \\
\hline Diffüz saç seyrelmesi & $1(1)$ & 0 & 1 & 0 \\
\hline Granulom anülare & $1(1)$ & 1 & 0 & 0 \\
\hline Ekskoriye plak, nodül & $1(1)$ & 1 & 0 & 0 \\
\hline
\end{tabular}

Grup 1: Transplantasyon süresi 0-5 yll olan hastalar, Grup 2: Transplantasyon süresi 5-10 yll olan hastalar, Grup 3: Transplantasyon süresi 10 yilın üzerinde olan hastalar 
deri belirtileri olarak kaydedilmiştir. Bu çalışmalarda hastaların \%68'inde yüzeyel mantar infeksiyonları saptanmış ve bunlar içerisinde onikomikoz $\% 58$, dermatofitler $\% 10$ ve pitriyazis versikolor $\% 6$ oranında tespit edilmiştir. Dosyaları taranan hastalarımızda mantar infeksiyonlarından onikomikoz tek başına ve/veya tinea pedis ile birlikte en sık gözlenen infeksiyon idi. Genel olarak baktığımızda normal populasyonda da mantar infeksiyonları en sık karşılaştığımız ve dermatoloji polikliniğine başvuruların önemli bir kısmını oluşturmaktadır . Bu nedenle mantar infeksiyonlarının görülme sıklığının fazla olmasını transplantasyon hastalarındaki immünsupresyona duruma bağlamak doğru olmayacaktır. Renal transplantasyon yapılan hastalarda gözlenen deri bulguları içinde bakteriyel infeksiyonlar önemli yer tutmaktaydı. Akneiform lezyonlar, eritrazma ve folikülit bu grup içinde sayılabilecek lezyonlardır. Sandoval

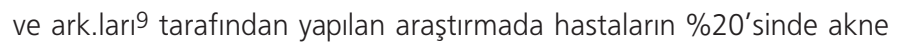
lezyonları tespit edilmiştir. Benzer bir çalışmada dermatolojik bulguları açısından takip edilen 54 transplant hastasından 10'unda $(\% 18,5)$ bakteriyel infeksiyona rastlanmıştır ${ }^{10}$. Bizim çalışmada da toplam 20 hastada (\%17) akneiform lezyonlar saptanmış olup sonuçlar birbirine yakındır. Hastalarda sıklıkla tespit edilen akneiform lezyonlar daha çok kortikosteroid kullanımına bağlı olarak transplantasyon sonrası ilk 5-10 yılda görülmüştür. Özellikle kortikosteroid ile takrolimusun birlikte kullanıldığı grupta daha fazla sayıda hastada (17) tespit edilmiştir. Viral deri infeksiyonları İtalya'da yapılan bir çalışmada 109 transplant hastasında değerlendirilmiş ve en sık görülen deri bulgusu olarak saptanmışıı10. Aynı şekilde Ghaninejad ve arkadaşları tarafından yapılan bir çalışmada renal transplantasyon yapılan 100 hastada en çok viral infeksiyonlar tespit edilmiştir ${ }^{8}$. Sandoval ve arkadaşları tarafından yapılan bir diğer çalışmada ise deri bulgularından verrukalar ikinci sırada yer almıştır ${ }^{9}$. Bu çalışmalarda görülme sıklığı olarak verrukalar ilk sırada ve ikinci sırada yer almıştır. Çalışmamızda deri bulguları arasında üçüncü sırada görülen viral infeksiyonlardan verrukalar hastalarımızda en sık oranda tespit edildi. Dış ortamla temasta olan bölgelerde yani ekstremiteler ve gövdede genital bölgeye göre daha sık oranda verrukalar tespit edildi. Bunun nedeni olarak görünen bölgelerde yerleşen verrukalarda ultraviyolenin immünsupresif etkilerinin belirgin olması düşünülebilir14. Transplantasyon süresi göz önüne alındığında verrukaların transplantasyondan 5-10 yıl sonra ön plana çıktığı tespit edildi. Bulgumuzu destekler nitelikte Dyall-Smith ve arkadaşları tarafından yapılan çalışmada 5 yıldan fazla üzerinden geçen hastalarda \%92 oranda verrukalar tespit edilmiş ve bu hastaların $\% 65^{\prime}$ inde sayı olarak $5^{\prime}$ den fazla siğil görülmüştür 15 . Sonuç olarak viral infeksiyonlardan özellikle verrukaların immünsupresyonla bağlantılı olarak ortaya çıktığı söylenebilir.

Renal transplant hastalarında immünsupresif tedaviye bağlı olarak fırsatçı infeksiyonlarda benzer bir artış düşünülebilir. Çalışmalarda Pneumocystis carinii pneumonia, Cytomegalovirus ve Epstein-Barr virus gibi fırsatçı infeksiyonlar tespit edilmiştır6,7. Bizim yaptığımız dosya taramalarında fırsatçı infeksiyona rastlanmadı. Taranan 116 hastanın dışında sadece bir hastada tipi belirlenemeyen kandida enfeksiyonuna rastlanmış olup infeksiyon hastalıkları tarafından tedavisi planlanmıştır.
Literatür değerlendirmesi yapıldığında renal transplantasyon yapılan hastalarda deri bulgularının genellikle immünsupresyona ikincil geliştiği görülmektedir14,15. Aktinik keratoz, BHK, skuamöz hücreli kanser, kaposi sarkomu en çok karşılaştığımız premalin ve malin lezyonlardır. Vijayakumar ve arkadaşları 1987-1996 yılları arasında 340 transplant hastasını takip etmiş olup bu hastalarda toplam 6 olguda premalin ve malin lezyon ( 2 aktinik keratoz, 3 kaposi sarkomu, 1 BHK) tespit etmişlerdir11. Bizim çalışmamızda benzer şekilde premalin ve malin lezyonların tüm hastalarda düşük oranda görüldüğü tespit edildi. Burada akla gelebilecek premalin ve malin lezyonların transplantasyon yılı ile ilgili olabileceği görüşü de çok geçerli görülmemektedir. Bu lezyonların transplantasyon yılı artan hastalarda daha fazla oranda görüldüğüne ait bulgu tespit edilmedi. Bu durumda hastaların periyodik dermatolojik değerlendirmesinin erken lezyonların tespitinde ve risk faktörlerinin değiştirilmesinde ne kadar önemli olduğu bilinmemektedir.

Hastaların 6 ay sonraki takipleri değerlendirildiğinde sık görülen bulguların sayıca azalmakla birlikte başlangıçta en sık görülen deri lezyonlarına benzer şekilde yüzeyel mantar infeksiyonları ve akneiform lezyonlar olduğu belirlendi. Deri lezyonu olan hasta sayılarında tespit edilen az miktardaki azalma bazı hastaların verilen spesifik ajanlar ile tedavi edilmesine bağlandı. Genellikle hastaların tedaviye uyumu iyi değildi. Bunun nedeni hastaların şikayetlerinin farkında olmaması ve çoğu şikayetin rutin muayene sırasında tespit edilmesiydi. Viral infeksiyonlarda belirgin bir azalma tespit edildi. Altı ay sonraki takipte 15 hastada görülen viral infeksiyon sadece 4 hastada izlendi. Viral infeksiyon sayılarındaki azalma antiviral tedavinin etkinliğini göstermektedir. Premalin malin lezyonlar açısından süreye göre bir değişiklik olmaması takip sürelerinin en az bir yıl veya daha uzun olması gerektiği şeklinde yorumlanabilir.

Dermatolojik muayenede tespit edilen kserosis, hiperpigmentasyon, kuperoz ve ekzema gibi klinik tanılar hastaların immünsupresif durumları ile doğrudan bağlantılı olarak düşünülmedi. Kadın hastalarda 6 aylık takip sonunda tespit edilen seboreik dermatit görülme oranındaki artış tesadüfi bir bulgu olarak değerlendirildi ve stres faktörünün rol oynayabileceği düşünüldü. Dermatolojik muayene sırasında hastalarda genel olarak saçlarda belli oranlarda kayıp ve incelme gözlendi. Bu durum hastaların hemen tamamında gözlendi. Genel olarak immünsüpresyonun uzun sürede etkili olduğu hastalarda daha belirgin olarak gözlendi. İmmünsüpresyona veya kronik hastalığa bağlı effluvium olabileceği düşünüldü.

\section{Kaynaklar}

1. Sever MŞ: Türkiye'de böbrek transplantasyonu sorunları ve çözüm önerileri. Türk Nefroloji Diyaliz ve Transplantasyon Dergisi 2008;17(Suppl 1):3-8.

2. US Renal Data System. USRDS 2001 Annual Report. Bethesda, MD: National Institute of Health, 2001.

3. Bia M, Adey DB, Bloom RD, et al: KDOQI US commentary on the 2009 KDIGO clinical practice guideline for the care of kidney transplant recipients. Am J Kidney Dis 2010;56:189-218.

4. Maraki S: Venereol epidemiology of dermatophytoses in Crete, Greece between 2004 and 2010. G Ital Dermatol 2012;147:315-9.

5. Wang YB, Han T, Zhao CX: Prevalence of human papillomavirus in the pubic hair follicles of healthy men and male patients with genital warts. Zhonghua Nan Ke Xue 2010; 16:783-5.

6. A Kwok, Sayeed M: Infections in renal transplant recipients management challenging and preventation key. Nephrology Times 2008;1:2-3. 
7. Shuttleworth D, Philpot CM, Salaman JR: Cutaneous fungal infection following renal transplantation: a case control study. $\mathrm{Br} J$ Dermatol 1987; 117:585-90.

8. Ghaninejad $H$, Ehsani $A H$, Ghiasi $M$, et al : Benign and malignant skin lesions in renal transplant recipients. Indian J Dermatol 2009;54:247-50.

9. Sandoval M, Ortiz M, Díaz C, Majerson D, Molgó M: Cutaneous manifestations in renal transplant recipients of Santiago, Chile. Transplant Proc 2009;41:3752-4.

10. Prakash J, Singh S, Prashant GK, et al: Mucocutaneous lesions in transplant recipient in a tropical country. Transplant Proc 2004;36:2162-4.
11. Vijayakumar R, Fernando E, Rajendran S, Jayakumar M, Muthusethupathi MA: Dermatological manifestations in renal transplant recipients. Transplant Proc 1998;30:3136.

12. Abel EA: Cutaneous manifestations of immunosuppression in organ transplant recipients. J Am Acad Dermatol 1989;21:167-79.

13. Wolfson IS, Sober AJ, Rubin RH: Dermatologic manifestations of infections in immunocompromised patients. Medicine (Baltimore) 1985;64:115-33.

14. Demirgüneş EF, Evans S, Yılmaz R, Şahin S, Yasavul Ü: Renal transplantasyon hastalarında gözlenen deri bulguları. Türkderm 2008;42:18-21.

15. Dyall-Smith D, Trowell H, Dyall-Smith ML: Benign human papillomavirus infection in renal transplant recipients. Int J Dermatol 1991;30:785-9. 